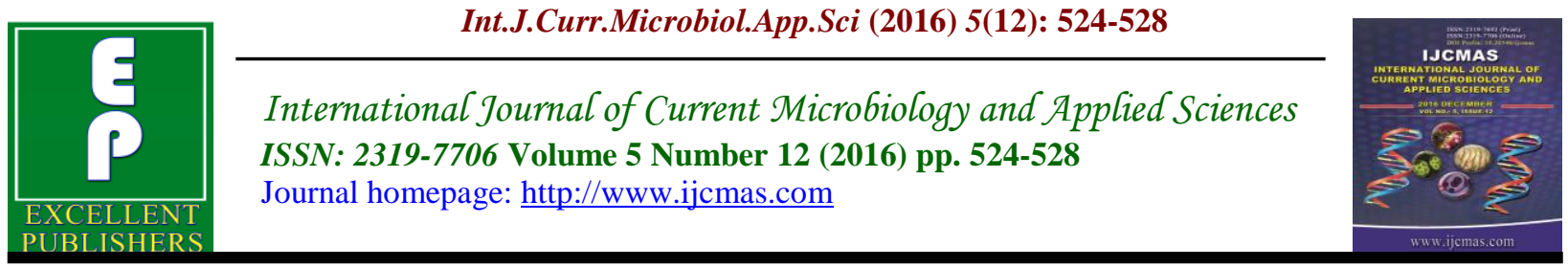

Original Research Article

http://dx.doi.org/10.20546/ijcmas.2016.512.057

\title{
Sero-Prevalence of Hepatitis ' $B$ ' Virus Infection: A Teaching Hospital Based Study
}

\author{
Sunil Hatkar ${ }^{1 *}$, Jaya Baviskar ${ }^{2}$ and Santosh Kotgire ${ }^{3}$ \\ ${ }^{1}$ Department of Microbiology, SMBT Medical College, Dhamangaon, Nashik, Maharashtra, India \\ ${ }^{2}$ Department of Pathology, IIMSR Medical College, Jalna, (MS)-431202, India \\ ${ }^{3}$ Department of Microbiology, IIMSR Medical College, Jalna, (MS)-431202, India \\ *Corresponding author
}

\begin{tabular}{|c|c|}
\hline & A B S T R A C T \\
\hline Keywords & \multirow{4}{*}{$\begin{array}{l}\text { Present study was carried out to find out seropositivity of HBsAg among the } \\
\text { hospital based population. A total of } 6575 \text { blood samples were collected from } \\
\text { outdoor and indoor patients were further subjected rapid immunoassay for the } \\
\text { detection of Hepatitis B surface antigen. Result: A total of } 6575 \text { serum } \\
\text { samples were screened for Hepatitis-B surface antigen, out of which } 4669 \\
\text { samples were from outdoor patients and } 1906 \text { samples were from indoor } \\
\text { patients. The result of HBsAg rapid screening reveals that overall } \\
\text { seropositivity is } 72(1.10 \%) \text { in our hospital based population. Conclusion: } \\
\text { Present study concludes that the control and prevention of HBV infection } \\
\text { require continuous monitoring as well as evaluation of prevention and } \\
\text { surveillance strategies. }\end{array}$} \\
\hline $\begin{array}{l}\text { HBsAg, } \\
\text { blood samples, } \\
\text { rapid immunoassay } \\
\text { Sero-prevalence. }\end{array}$ & \\
\hline Article Info & \\
\hline $\begin{array}{l}\text { Accepted: } \\
18 \text { November } 2016 \\
\text { Available Online: } \\
10 \text { December } 2016\end{array}$ & \\
\hline
\end{tabular}

\section{Introduction}

Hepatitis B virus (HBV) belongs to the family of hepadnaviruses and replicates by reverse transcription via an RNA intermediate, making it prone to mutations and is an etiologic agent of hepatocellular carcinoma (Ganem et al., 2004). HBV has long incubation period (45-120 days) and is transmitted primarily by parenteral means (Hollinger et al., 2001).

HBV infection is a global public health problem with more than 350 million persons estimated to be chronically infected with the virus and is the ninth major cause of mortality (Goldstein et al., 2005). HBV carriers' population estimated for $4 \%$ and near about 36 million populations are HBV carriers in India More than $70 \% \mathrm{HBV}$ infective patient accounted with cases of hepatocellular carcinoma, liver cirrhosis and hepatitis virus associated liver disease. In contrast to hepatitis A virus, hepatitis B virus may produce fulminant fatal acute hepatitis, called massive hepatic necrosis. Until routine screening of blood products for this virus was begun, hepatitis B was the most common cause of transfusionassociated hepatitis (Nguyen et al., 2009).

Hepatitis B antigen has been demonstrated in mosquitoes, but transmission of infection by arthropods has not been authenticated 
(Hollinger et al., 2001). Hepatitis B virus can be transmitted through blood and blood related products. Because of the extremely high infectivity titer of $>10^{8} / \mathrm{ml}$ serum, even the slightest trace of serum is dangerous, but other bodily secretions such as saliva, ejaculate, vaginal secretions or menstrual blood may also cause transmission, and titres of $10 \% \mathrm{ml}$ may be present in these materials. HBsAg and HBV DNA have been detected in Urine (Mikael et al., 2000), but there is no epidemiological evidence that the infection is transmitted by exposure to urine. Transmission is most efficient by intravenous injection, 100 times less efficient by intramuscular or percutaneous route and least efficient by mucosal contact. Perinatal infection occurs, but breast milk does not appear to play a role in transmission.

Control of HBV includes counseling of HBV carriers, general hygiene, disinfection, blood screening, active and passive immunization, and treatment of persistent infection. Diagnosis of $\mathrm{HBV}$ on routine basis is most important to overcome the situation (Prevention of hepatitis B in India, 2002).

The screening of HBV infection is usually done by detecting Hepatitis B surface antigen (HBsAg) which is express by Hepatitis B Virus very early, and is the first serological marker to appear in acute HBV infection and persistence of $\mathrm{HBs} \mathrm{Ag}$ for more than 6 months suggest chronic HBV infection (Huang et al., 2006). Recently, quantitative HBsAg level determination has been proposed to differentiate inactive HBsAg carriers from persons with active disease (Brunetto et al., 2010).

Serological and virological markers are available to detect Hepatitis B Viral antigen (Iloeje et al., 2000). Virological markers are expensive and usually the facility is not available in resource constraint setting. Rapid Immunoassay is one of the best, reliable, cost effective, and result can be obtained within 20 minutes.

Present study was an attempt to know the seropositivity of Hepatitis B surface antigen by rapid immunoassay in our region.

\section{Materials and Methods}

After the approval of institutional ethical committee, the Prospective Hospital Based Study was carried out at IIMSR Medical College, Warudi (Central Clinical Laboratory) during the period of Jan-2016 to April-2016.

A total of 6575 non-repetitive blood samples from the Patients attending OPD \& IPD were included in the study. Patients with HIV comorbidities were excluded from the study.

About $2 \mathrm{ml}$ of venous blood sample was collected, left to clot for 15 minutes at room temperature. Sera were separated by using micropipette. The serum sample were further subjected to a visual, rapid, sensitive and accurate one step immunoassay for the qualitative detection of Hepatitis B Surface Antigen (HBsAg) in Human Serum which were procured from J. Mitra \& Co. Pvt. Ltd. Two drops of serum specimen were added in sample well by using dropper provided with test kit. Results were noted after 20 minutes. Those samples which were reactive for HBsAg, were confirmed by same method using different manufactured kit. Results were calculated by using windows based excel program.

\section{Results and Discussion}

A total 6575 serum samples were screened for Hepatitis-B surface antigen detection as 
per standard guidelines. Out of which 4669 samples were from OPD patients and 1906 samples were from IPD patients. Those samples were reactive for $\mathrm{HBsAg}$ were confirmed by same method using different manufactured kit. Following results were obtained and calculated by statistical analysis (Table-1).

The rapid immunoassay reveals that the overall sero-positivity of HBsAg was $72(1.10 \%)$. It was also noted that the prevalence of $\mathrm{HBV}$ is more in OPD patients $(1.41 \%)$ than IPD patients $(0.31 \%)$ (Table- 1$)$

Viral hepatitis infections remain an important health and socioeconomic problem worldwide, despite continued progress in their prevention and treatment.
The periodic evaluation of epidemiological data is important to better assess the health status of populations and for preparing more accurate future health strategies. Number of studies that has been carried out across the world and it was noted that the prevalence of $\mathrm{HBV}$ infection varies with different geographical areas which depend upon complex interplay of behavioral, environmental, poor health and hygiene.

Present study was an attempt to detect seropositivity of hepatitis B surface antigen in our region. A total of 6575 serum samples were screened for Hepatitis-B surface antigen, out of which 4669 samples were from OPD patients and 1906 samples were from IPD patients.

Table.1 Seropositivity of Hepatitis-B Surface Antigen in OPD \& IPD (N=6575)

\begin{tabular}{|c|c|c|c|}
\hline \multicolumn{5}{|c|}{ Hepatitis-B surface antigen results } \\
\hline & Positive & Negative & Total \\
\hline OPD (Outdoor patients) & $66(1.41 \%)$ & $4603(98.59 \%)$ & 4669 \\
\hline IPD (Indoor patients) & $06(0.31 \%)$ & $1900(99.69 \%)$ & 1906 \\
\hline Total & $\mathbf{7 2 ( 1 . 1 0 \% )}$ & $6503(98.90 \%)$ & 6575 \\
\hline
\end{tabular}

Fig.1 Seropositivity of Hepatitis-B Surface Antigen in OPD \& IPD (N=6575)




The result of HBsAg rapid screening reveals that overall seropositivity is $72(1.10 \%)$ in our hospital based population. Various studies carried out in India shows that prevalence of $\mathrm{HBV}$ infection ranging from $1 \%$ to $15 \%$. In a study conducted by Bhattacharya et al., (2005) overall seropositivity of $\mathrm{HBsAg}$ was $1.66 \%$ which is in concordance with present study, while Martha Baskar Rao (2006) Reported 7.6 \% seropositivity of HBsAg.

A study carried out Makroo et al., (2015) reported year wise data (2005-2013) of seroprevalance of $\mathrm{HBV}$, and it is ranging from $0.92 \%$ to $1.75 \%$ which indicates that consistent HBV infection.

It was also noted that the prevalence of $\mathrm{HBV}$ is more in OPD patients $(1.41 \%)$ than IPD patients $(0.31 \%)$.

The diagnosis of HBV infection on routine screening pattern basis is most important to overcome the situation. Detecting trace level of $\mathrm{HBsAg}$ represents a significant improvement in the diagnosis of $\mathrm{HBV}$ by using novel methods.

This study has some limitations; Rapid immunoassay is less sensitive than amplification assay but, due to resource constraint setting, Amplification was not done. However, Rapid immunoassay is one of the best, reliable, easy, and cost effective for routine screening of $\mathrm{HBV}$ infection in developing countries.

In conclusion, HBV infection is worldwide and significant problem in public health. Despite progress in the diagnosis and treatment of viral hepatits, their occurrence is still high in some parts of the world. The control and prevention of HBV infection require continuous monitoring as well as evaluation of prevention and surveillance strategies.

\section{References}

Bhattacharya, P. et al. 2005. Significant increase in $\mathrm{HBV}, \mathrm{HCV}, \mathrm{HIV}$ and syphilis infections among blood donors in West Bengal, Eastern India 2004-2005: Exploratory screening reveals high frequency of occult HBV infection. World J. Gastroenterol., 21: 3730-37.

Brunetto, M.R., et al. 2010. Hepatitis B surface antigen serum levels help to distinguish active from inactive hepatitis B virus genotype D carriers. Gastroenterol., 139(2): 483-90.

Chen, C.J., et al. 2006. Risk of hepatocellular carcinoma across a biological gradient of serum hepatitis B virus DNA level. JAMA, 295: 65-73.

Ganem, D., Price, A.M. 2004. Hepatitis B Virus infection-natural history and clinical consequences. $N$. Engl. J. Med., 350: 1118-29.

Gilson, R.J. et al. 1992. Sexually transmitted hepatitis: A review. Genitourin Med., 68: 123-129.

Goldstein, S.T. et al. 2005. "A mathematical model to estimate global hepatitis B disease burden and vaccination impact", Int. J. Epidemol., 34(6): 1329-39.

Hollinger, F.B., Liang, T.J. 2001. Hepatitis B Virus. In: Knipe DM, Howley PM, eds. Field virology. Ed.4. Philadelphia: Lippincott Williams \& Wilkins, 799-840.

Huang, Y.W., et al. 2006. Higher cut-off index value of immunoglobulin $M$ antibody to hepatitis B core antigen in Taiwanese patients with hepatitis B. $J$. Gastroenterol. Hepatol., 21: 859-862.

Iloeje, U.H., et al. Predicting liver cirrhosis risk based on the level of circulating hepatitis B viral load. Gastroenterol., 130: 678-86. 
Keeffe, E.B. et al. 2006. A treatment algorithm for the management of chronic hepatitis B virus infection in the United States: an update. Clin. Gastroenterol. Hepatol., 4: 936-62.

Makroo, R.N. et al. 2015. Seroprevalence of infectious markers \& their trends in blood donars in a hospital based blood bank in north India. Indian J. Med. Res., 142: 317-322.

Maratha Bhaskar Rao. 2012. The prevalence of hepatitis B in India and its prevention with Ayurveda. NAMAH, 19(4).

Mikael Knutsson, Karin Kidd-Ljunggren. 2000. Urine from chronic hepatitis B virus carriers: Implications for infectivity. J. Med. Viro., 60(1): 1720.

Mitra, J. Co. Pvt. Ltd. One Step Rapid Visual Test for the Qualitative
Detection of HBsAg in Human Serum/Plasma-"HEPACARD"

Instructions manual-A 180-181, Okhla Ind. Area, Ph-1, New Delhi-110 020 INDIA. www.jmitra.co.in.

Nguyen, V.T., Law, M.G., Dore, G.J. 2009. Hepatitis B-related hepatocellular carcinoma: epidemiological characteristics and disease burden. $J$. Viral. Hepat., 16(7): 453-63.

Prevention of hepatitis B in India, An overview. 2002. World Health Organization. New Delhi.

Sherman, M., Shafran, S., Burak, K. et al. 2007. Management of chronic hepatitis B: consensus guidelines. Can. J. Gastroenterol., 21(Suppl. C):5C-24C.

\section{How to cite this article:}

Sunil Hatkar, Jaya Baviskar and Santosh Kotgire. 2016. Sero-Prevalence of Hepatitis 'B' Virus Infection: A Teaching Hospital Based Study. Int.J.Curr.Microbiol.App.Sci. 5(12): 524-528. doi: http://dx.doi.org/10.20546/ijcmas.2016.512.057 